\title{
SPOŁECZNA INSPEKCJA PRACY - NIEDOSKONAŁOŚCI REGULACJI PRAWNEJ
}

\begin{abstract}
Social labour inspection - imperfection of regulation

The aim of the present study is drawing attention to a problem of social labour inspection. The author analyzes three problematic issues in the present legal state: organisation of social labour inspection, election of social labour inspectors and number of social labour inspectors.
\end{abstract}

Słowa kluczowe: społeczna inspekcja pracy, organizacja społecznej inspekcji pracy, wybór społecznych inspektorów pracy, liczba społecznych inspektorów pracy, zbiorowe prawo pracy

Key words: social labour inspection, organisation of social labour inspection, election of social labour inspectors, number of social labour inspectors, collective labour law

\section{Uwagi wstępne}

Zdrowie i życie ludzkie jest szczególnym dobrem, które podlega ochronie prawnej także w kontekście wykonywania pracy. Ochrona zdrowia i życia osób świadczących pracę znajduje oparcie w prawie międzynarodowym i unijnym ${ }^{1}$. Stanowi o niej również Konstytucja RP, która przewiduje z jednej strony zasadę ustrojową, realizowaną w ustawodawstwie zwykłym, zgodnie z którą praca znajduje się pod ochroną Rzeczypospolitej Polskiej, a państwo sprawuje nadzór nad warunkami jej wykonywania (art. 24), z drugiej strony - prawo każdego do bezpiecznych i higienicznych warunków pracy, którego sposób realizacji oraz obowiązki pracodawcy określa ustawa (art. 66 ust. 1)2.

$\mathrm{W}$ ustawodawstwie zwykłym i aktach wykonawczych można znaleźć wiele rozwiązań i instytucji mających na celu ochronę zdrowia i życia pracujących. Znaczną ich część

1 Szerzej na ten temat zob. np. T. Wyka, Ochrona zdrowia i życia pracownika jako element treści stosunku pracy, Warszawa 2003, s. 67 i n.; L. Florek, Europejskie prawo pracy, Warszawa 2010, s. 207-221 oraz A. Świątkowski, Międzynarodowe prawo pracy, t. I, Międzynarodowe publiczne prawo pracy - standardy międzynarodowe, vol. 3, Warszawa 2008, s. 51-200.

2 Szerzej zob. między innymi T. Wyka, Ochrona..., s. 105 i n. oraz A. Sobczyk, Prawo pracy w świetle Konstytucji RP, t. I, Teoria publicznego i prywatnego indywidualnego prawa pracy, Warszawa 2013, s. $46-55$ i $161-192$. 
stanowią rozwiązania i instytucje indywidualnego prawa pracy. Szczególne miejsce zajmuje wśród nich podstawowa zasada prawa pracy, jaką jest obowiązek pracodawcy zapewnienia pracownikom bezpiecznych i higienicznych warunków pracy (art. $15 \mathrm{kp}$ ). Zasada ta odnosi się - podobnie zresztą, jak i pozostałe rozwiązania indywidualnego prawa pracy - nie tylko do pracowników, lecz także do innych osób wykonujących pracę (art. $304 \mathrm{kp}$ ). Istotne są również instytucje zbiorowego prawa pracy, które służą na ogół bezpośrednio ochronie zdrowia i życia pracowników, ale przyczyniają się też do zwiększenia bezpieczeństwa i higieny pracy niepracowników. Warto tutaj zwrócić uwagę na zakładowe (międzyzakładowe) organizacje związkowe, które są w szerokim zakresie uprawnione do podejmowania różnorodnych działań mających na celu zapewnienie wszystkim zatrudnionym bezpiecznych i higienicznych warunków pracy ${ }^{3}$. Jednym z przejawów ich aktywności w tym zakresie jest kierowanie działalnością społecznej inspekcji pracy (art. 26 pkt 4 ustawy o związkach zawodowych ${ }^{4}$ ).

Społeczna inspekcja pracy ma już kilkudziesięcioletnią tradycję. Instytucja ta została wprowadzona w Polsce ustawą z lutego 1950 r. o społecznej inspekcji pracy ${ }^{5}$. Była ona pomyślana jako szczególna część systemu inspekcji pracy - szczególna, bo tworzona w zakładzie pracy przez samych pracowników. Od początku inspekcja łączyła w sobie elementy czynnika społecznego i organu posiadającego uprawnienia władcze wobec pracodawcy ${ }^{6}$. Jej społeczny charakter znajdował wyraz w dokonywaniu wyboru społecznych inspektorów pracy przez załogę lub mężów zaufania, w ścisłym powiązaniu tych inspektorów z radą zakładową i jej organami oraz w pełnieniu przez nich funkcji $\mathrm{z}$ reguły poza godzinami pracy i bez wynagrodzenia ${ }^{7}$. Z kolei uprawnienia władcze upodabniały rolę społecznych inspektorów pracy do tej pełnionej przez inspektorów nadzorujących zakład pracy w imieniu państwa od zewnątrz ${ }^{8}$.

Ustawę z lutego 1950 r. zastąpiła w czerwcu 1983 r. nowa ustawa o społecznej inspekcji pracy . Obowiązuje ona już od ponad 30 lat. W tym czasie znowelizowano ją tylko pięciokrotnie, wprowadzając drobne zmiany. Może to sugerować, że przepisy tej ustawy odpowiadają zasadom techniki prawodawczej ujętym w rozporządzeniu w sprawie „Zasad techniki prawodawczej”"10, a zwłaszcza są na tyle jasne, precyzyjne i wyczerpujące, że nie wywołują większych wątpliwości interpretacyjnych, które mogłyby

3 Zob. np. T. Wyka, Ochrona zdrowia i życia pracowników jako zadanie zwiąku zawodowego, w: Związkowe przedstawicielstwo pracowników zakładu pracy, Z. Hajn (red.), Warszawa 2012, s. 383 i n. oraz J. Piątkowski, Uprawnienia zakładowej organizacji związkowej, Toruń 2008, s. 253 i n.

4 Ustawa z dnia 23 maja 1991 r. o związkach zawodowych (Dz. U. z 2015 r., poz. 1881).

5 Ustawa z dnia 4 lutego 1950 r. o społecznej inspekcji pracy (Dz. U. z 1955 r., Nr 20, poz. 134 ze zm.).

6 Zob. W. Szubert, Ochrona pracy. Studium społeczno-prawne, Warszawa 1966, s. 133.

7 Tamże.

8 Tamże.

9 Ustawa z dnia 24 czerwca 1983 r. o społecznej inspekcji pracy (Dz. U. z 2015 r. poz. 567).

10 Rozporządzenie Prezesa Rady Ministrów z dnia 20 czerwca 2002 r. w sprawie „Zasad techniki prawodawczej" (Dz. U. z 2016 r. poz. 283). 
wpływać negatywnie na praktykę ich stosowania. Gdyby było inaczej, ustawodawca zapewne by interweniował, dokonując niezbędnych zmian.

Czy obowiązująca ustawa o społecznej inspekcji pracy rzeczywiście jednak wyróżnia się wysokim poziomem legislacyjnym? A może wymaga ona nowelizacji lub zastąpienia jej zupełnie nową ustawą? Aby udzielić odpowiedzi na te pytania, należy przeanalizować jej przepisy. W związku z tym, że nie jest możliwe z oczywistych względów przeanalizowanie w niniejszym opracowaniu całej ustawy o społecznej inspekcji pracy, poczynione niżej rozważania koncentrują się na ustaleniu, jak przepisy tej ustawy regulują organizację inspekcji oraz wybór i liczbę inspektorów.

\section{Ustawowy model organizacyjny inspekcji}

Jak wynika $z$ art. 3 ust. 1 ustawy, społeczną inspekcję pracy tworzą grupowi społeczni inspektorzy pracy - dla komórek organizacyjnych oddziałów (wydziałów), oddziałowi (wydziałowi) społeczni inspektorzy pracy - dla poszczególnych oddziałów (wydziałów), a także zakładowy społeczny inspektor pracy - dla całego zakładu pracy. Przepis ten zdaje się jasno określać organizację inspekcji. Zgodnie z modelem przyjętym w ustawie społeczni inspektorzy pracy działają u pracodawcy w obrębie komórek organizacyjnych oddziałów (wydziałów), na poziomie samych oddziałów (wydziałów) oraz w ramach całego zakładu pracy. W zależności od struktury organizacyjnej danego pracodawcy inspektorzy pełnią funkcję na wszystkich wymienionych szczeblach lub tylko na niektórych z nich, przy czym niezbędne jest działanie społecznego inspektora pracy na poziomie zakładowym, ponieważ inspektor zakładowy korzysta z określonych uprawnień władczych na zasadzie wyłączności. Jeżeli u pracodawcy nie ma oddziałów (wydziałów) i co za tym idzie - komórek organizacyjnych tych jednostek, inspektor zakładowy jest co zrozumiałe - jedynym społecznym inspektorem pracy. Natomiast w przypadku gdy struktura organizacyjna pracodawcy jest bardziej rozbudowana, inspektorowi zakładowemu towarzyszą inspektorzy oddziałowi (wydziałowi), a gdy w ramach oddziałów (wydziałów) występują komórki organizacyjne - również inspektorzy grupowi.

Artykuł 3 ustawy zawiera jednak nie tylko ustęp 1, na podstawie którego można wyprowadzić przedstawione wyżej, dość oczywiste, wnioski, lecz także ustęp 2, zgodnie z którym zakładowe organizacje związkowe dostosowują organizację społecznej inspekcji pracy do potrzeb wynikających ze struktury zakładu pracy. Poprzez wprowadzenie tego przepisu chciano zapewne zagwarantować pewien stopień elastyczności organizacji społecznej inspekcji pracy. Przepis ten budzi jednak zastrzeżenia. Można się mianowicie zastanawiać, czy w świetle powyższego unormowania zakładowe organizacje związkowe dysponują pełną swobodą w zakresie dostosowywania organizacji inspekcji do potrzeb determinowanych strukturą zakładu pracy według własnych subiektywnych zapatrywań. Czy mogą one na przykład przyjąć - co niekiedy się zdarza - że u pracodawcy działa tylko zakładowy społeczny inspektor pracy, pomimo że struktura organizacyjna pracodawcy obejmuje oddziały (wydziały) podzielone na komórki organizacyjne? Na podstawie art. 3 
ust. 2 ustawy trudno jest jednoznacznie ocenić legalność takiej praktyki ${ }^{11}$. Przepis ten zdaje się zbyt ogólny. Jedna z zasad techniki prawodawczej stanowi wprawdzie, że jeżeli zachodzi potrzeba zapewnienia elastyczności tekstu aktu normatywnego, można posłużyć się określeniami nieostrymi, klauzulami generalnymi albo wyznaczyć nieprzekraczalne dolne lub górne granice swobody rozstrzygnięcia ( $\$ 155$,Zasad techniki prawodawczej”), ale nie należy - jak się wydaje - wyprowadzać z tego wniosku o dopuszczalności przyznania adresatom normy pełnej dowolności działania. Tymczasem art. 3 ust. 2 ustawy nie wyznacza granic możliwego dostosowywania przez zakładowe organizacje związkowe organizacji inspekcji do potrzeb wynikających ze struktury zakładu pracy. Skoro zaś nie ma wyznaczonych granic działania organizacji związkowych, nie ma też z oczywistych względów uregulowanych skutków ich przekroczenia.

Wydaje się, że na pewne granice działania organizacji związkowych wskazuje tutaj cel regulacji. Na podstawie wykładni celowościowej można bowiem zasadnie twierdzić, że wprowadzanie ewentualnych odstępstw od modelu organizacyjnego inspekcji przewidzianego $\mathrm{w}$ art. 3 ust. 1 ustawy powinno być motywowane troską o zagwarantowanie społecznym inspektorom pracy właściwych warunków do wykonywania przysługujących im uprawnień tak, aby mogli jak najskuteczniej realizować cel inspekcji, jakim jest zgodnie z art. 1 ustawy zapewnienie przez pracodawcę bezpiecznych i higienicznych warunków pracy oraz ochrona uprawnień pracowniczych, określonych w przepisach prawa pracy. Należy przypuszczać, że rezygnacja z wyboru oddziałowych (wydziałowych) i grupowych społecznych inspektorów pracy rzadko kiedy - o ile w ogóle - temu służy. Jeżeli bowiem pracodawca ma rozbudowaną strukturę organizacyjną, ograniczenie obecnej u niego społecznej inspekcji pracy do aktywności jedynie inspektora zakładowego utrudnia, a w skrajnych przypadkach nawet uniemożliwia efektywne działanie tego inspektora na rzecz poprawy bezpieczeństwa i higieny pracy oraz ochrony uprawnień pracowniczych.

O ile na podstawie wykładni celowościowej można wyznaczyć pewne granice dopuszczalnego dostosowywania organizacji inspekcji do potrzeb wynikających ze struktury pracodawcy, o tyle nie sposób w ogóle określić skutków ich przekroczenia ani wskazać podmiotów, które mogłyby ewentualnie decydować o wystąpieniu tych skutków. Stąd niezbędna wydaje się interwencja ustawodawcy, która powinna sprowadzać się do zakreślenia granic możliwego wprowadzania odstępstw od modelu organizacyjnego inspekcji przewidzianego w ustawie, wskazania skutków prawnych przekroczenia tych granic oraz podmiotów kompetentnych do dokonywania ustaleń w tym przedmiocie. W kontekście zaś zgłoszonego niżej postulatu uniezależnienia społecznej inspekcji pracy od związków zawodowych warto też rozważyć zmianę podmiotu uprawnionego do dostosowywania organizacji inspekcji do potrzeb determinowanych strukturą pracodawcy.

11 Za prawną dopuszczalnością ograniczania szczebli, na których działają społeczni inspektorzy pracy, opowiada się W. Kozieł, Ustawa o społecznej inspekcji pracy. Komentarz, Warszawa 1988, s. 15. Podobnie D. Książek, Ustawa o społecznej inspekcji pracy, w: Zbiorowe prawo pracy, K. Baran (red.), Warszawa 2014, s. 912. 


\section{Wybór społecznych inspektorów pracy}

De lege lata zakładowe (międzyzakładowe) organizacje związkowe odgrywają ważną rolę przy wyłanianiu społecznych inspektorów pracy. Świadczy już o tym chociażby fakt, że społeczna inspekcja pracy może zostać utworzona, a społeczni inspektorzy pracy wyłonieni tylko u pracodawcy, u którego jest obecna przynajmniej jedna zakładowa (międzyzakładowa) organizacja związkowa. Można mieć poważne zastrzeżenia do tego rozwiązania. O ile bowiem w 1983 r., kiedy uchwalono ustawę o społecznej inspekcji pracy, zdecydowaną większość pracodawców stanowiły duże przedsiębiorstwa objęte zakresem działania organizacji związkowych, o tyle obecnie jest zupełnie inaczej. Uzależnienie możliwości utworzenia społecznej inspekcji pracy i wyłonienia społecznych inspektorów pracy od obecności organizacji związkowych połączone z faktycznym brakiem tych organizacji u przeważającej większości pracodawców powoduje marginalizację znaczenia inspekcji i działających w jej ramach inspektorów, a przez to osłabienie ochrony pracowników ${ }^{12}$. Nawet u tych nielicznych pracodawców, u których są obecne związki zawodowe, nie zawsze powołuje się inspekcję. Decyzję o jej utworzeniu pozostawia się bowiem samym związkom.

Mając na względzie to, o czym wspomniano wyżej, oraz fakt, że działalność inspekcji oraz inspektorów ukierunkowana jest na ochronę tak ważnego dobra, jakim jest zdrowie i życie ludzkie, należy w pełni zgodzić się z postulatem zgłaszanym w nauce prawa pracy, aby społeczna inspekcja pracy została uniezależniona od organizacji związkowych ${ }^{13}$. $\mathrm{Za}$ realizacją tego postulatu przemawiają dodatkowo wątpliwości, jakie pojawiają się w odniesieniu do roli związków zawodowych w świetle aktualnie obowiązujących regulacji.

Zgodnie z art. 6 ust. 6 ustawy organizacje związkowe przeprowadzają wybory społecznych inspektorów pracy na podstawie uchwalonych przez siebie regulaminów wyborów. Co istotne, kształtując treść regulaminów, nie mogą one przyjmować rozwiązań, które byłyby sprzeczne z przepisami ustawy. Oznacza to między innymi, że organizacje związkowe nie mogą wprowadzić innego sposobu wyłaniania społecznych inspektorów pracy niż na drodze wyborów. Co więcej, muszą one tak ustalić szczegółowe kwestie dotyczące wyborów - np. określenie terminu i miejsca ich przeprowadzania czy sposobu, w jaki należy o tym informować u danego pracodawcy - aby wszyscy pracownicy mieli możliwość wzięcia w nich udziału.

Grupowych społecznych inspektorów pracy wybiera ogólne zebranie pracowników komórek organizacyjnych oddziału (wydziału). W przypadku natomiast oddziałowych (wydziałowych) społecznych inspektorów pracy i zakładowego społecznego inspektora pracy wybory mogą być bezpośrednie lub pośrednie w zależności od liczby pracowników.

12 W literaturze przedmiotu pisze się nawet o „swoistej atrofii tej instytucji” (tak W. Sanetra, Ochrona praw pracowniczych, w: Polskie prawo pracy w okresie transformacji w oświetleniu prawa wspólnotowego, H. Lewandowski (red.), Warszawa 1997, s. 135).

13 Zob. np. Z. Salwa, Uprawnienia związków zawodowych, Bydgoszcz 1998, s. 191 i M. Seweryński, Załoga zakładu pracy - uwagi de lege ferenda, w: Reprezentacja praw i interesów pracowniczych, G. Goździewicz (red.), Toruń 2001, s. 54-55. 
W oddziałach (wydziałach) lub zakładach pracy liczących do 300 pracowników inspektorów wybiera ogólne zebranie pracowników oddziału (wydziału) lub zakładu pracy. Jeżeli zaś w oddziałach (wydziałach) lub zakładach pracy zatrudnionych jest więcej niż 300 pracowników, wyboru inspektorów oddziałowych (wydziałowych) dokonuje zebranie inspektorów grupowych, a inspektora zakładowego - zebranie inspektorów oddziałowych (wydziałowych) i grupowych. W zakładach, w których nie wybrano inspektorów grupowych, tryb wyboru wskazanych inspektorów oddziałowych (wydziałowych) i zakładowego określają zakładowe organizacje związkowe.

Posiadanie czynnego prawa wyborczego przez wszystkich pracowników zatrudnionych u pracodawcy potwierdza, że niezależnie od powiązań inspekcji z organizacjami związkowymi jest ona organem załogi ${ }^{14}$. Teza ta znajduje również oparcie w przepisach art. 1 i 2 ustawy, z których wynika, że inspekcja jest służbą społeczną i reprezentuje interesy wszystkich pracowników ${ }^{15}$. Biorąc jednak pod uwagę cel działania inspekcji i inspektorów, warto rozważyć, czy podmiotem reprezentowanym nie powinni być wszyscy zatrudnieni u danego pracodawcy. Wydaje się, że wskazane byłoby przyznanie także niepracownikom prawa do głosowania w wyborach społecznych inspektorów pracy. Postulat ten wpisuje się w dyskusję, jaka toczy się aktualnie w sprawie rozszerzenia zakresu odniesienia zbiorowego prawa pracy na niepracowników.

Funkcję społecznego inspektora pracy też mogą pełnić obecnie tylko pracownicy danego pracodawcy. Ważne jest, aby nie zajmowali oni stanowiska kierownika zakładu pracy lub stanowiska kierowniczego bezpośrednio podległego kierownikowi zakładu, posiadali niezbędną znajomość zagadnień wchodzących w zakres działania inspekcji oraz mieli odpowiednio długi staż zakładowy i staż w branży, do której zakład należy ${ }^{16}$. Dodatkowy wymóg stanowi przynależność do związku zawodowego. Zakładowe (międzyzakładowe) organizacje związkowe mogą wprawdzie zrezygnować z tego wymagania, niemniej i tak budzi ono zastrzeżenia z punktu widzenia zasygnalizowanego już wyżej problemu zależności inspekcji i inspektorów od organizacji związkowych.

Jeżeli chodzi o bierne prawo wyborcze, przejawem tej zależności jest również posiadanie wyłącznie przez zakładowe (międzyzakładowe) organizacje związkowe uprawnienia do zgłaszania kandydatów na inspektorów. Warto zauważyć, że podobne rozwiązanie - z tym że dotyczące zgłaszania kandydatów na członków rady pracowników - zostało w 2008 r. uznane za niezgodne $\mathrm{z}$ art. 59 ust. $1 \mathrm{w}$ związku $\mathrm{z}$ art. $32 \mathrm{i}$ art. 31 ust. 3 Konstytucji RP ${ }^{17}$.

Poważnym mankamentem ustawy o społecznej inspekcji pracy świadczącym - jak się wydaje - o jej niezgodności z wymogiem wyczerpującego regulowania danej dziedziny

14 W. Sanetra, Ustawa o społecznej inspekcji pracy. Komentarz, w: Prawo socjalne, W. Sanetra (red.), Warszawa 2001.

15 Tamże.

16 Zakładowy społeczny inspektor pracy powinien posiadać co najmniej pięcioletni staż pracy w branży, do której zakład należy, i co najmniej dwuletni staż pracy w danym zakładzie, a oddziałowy lub grupowy społeczny inspektor pracy - co najmniej dwuletni staż pracy w tej branży i co najmniej jeden rok pracy w danym zakładzie.

17 Wyrok TK z dnia 1 lipca 2008 r., K 23/07, OTK - A 2008, nr 6, poz. 100. 
spraw (\$2 „Zasad techniki prawodawczej”) jest to, że nie określa ona skutków, jakie naruszanie przedstawionych wyżej regulacji wywołuje w zakresie dotyczącym statusu inspektorów ${ }^{18}$. Nie można jednak wyprowadzać $\mathrm{z}$ tego wniosku, iż naruszenia te nie powodują żadnych konsekwencji. Wydaje się, że niektóre z nich, a dokładniej te godzące $\mathrm{w}$ istotę zasady reprezentacji, wykluczają nabycie przez pracowników statusu inspektora.

Przede wszystkim chodzi tutaj o brak formalnego aktu wyboru. Jeżeli nie przeprowadzono wyborów, osoby rzeczywiście sprawujące funkcję społecznego inspektora pracy nie powinny być traktowane jak inspektorzy. Dotyczy to w szczególności pracowników, którzy po upływie czterech lat od wybrania ich do pełnienia tej funkcji nadal ją faktycznie wykonują ${ }^{19}$. Niewystarczająca wydaje się tutaj sama akceptacja pracowników dla dalszego sprawowania przez te osoby funkcji inspektora ${ }^{20}$. Zgodnie bowiem z ustawą pracownicy mają wybierać społecznych inspektorów pracy, a nie jedynie aprobować faktyczne pełnienie przez nich tej funkcji. Gdyby zresztą nawet nadać znaczenie prawne aprobacie pracowników dla rzeczywistego sprawowania funkcji inspektora przez osoby niewybrane do jej wykonywania, i tak pojawiłby się problem, na czym ta aprobata miałaby właściwie polegać. Na braku domagania się przeprowadzenia wyborów czy niezgłaszaniu sprzeciwu wobec pełnienia funkcji przez osoby niewybrane? Czy takie zachowanie pracowników rzeczywiście oznacza jednak akceptację przez nich faktycznych działań osób niewybranych na inspektorów? Pasywna postawa pracowników może przecież wynikać z różnych przyczyn, nie wyłączając braku zainteresowania wyborami czy nawet w skrajnym przypadku niewiedzy o obecności u pracodawcy inspekcji i inspektorów.

Skoro aprobata pracowników dla rzeczywistego sprawowania funkcji inspektora przez osoby niewybrane nie może zastąpić aktu wyboru, to tym bardziej tak jest w przypadku akceptacji wyrażanej w tym przedmiocie przez związki zawodowe i pracodawcę. Jeżeli chodzi o związki zawodowe, nie posiadają one prawa wyboru społecznych inspektorów pracy. Organizacje te mają - jak już była o tym mowa - przeprowadzać wybory na podstawie uchwalonych przez siebie regulaminów wyborów. Nie mogą zamiast tego zgadzać się na faktyczne wykonywanie funkcji przez osoby niewybrane ${ }^{21}$.

Z kolei w przypadku pracodawcy zasadne wydaje się twierdzenie, że jego postawa wobec osób rzeczywiście wykonujących funkcję inspektora bez formalnego aktu wyboru

18 Ustawa przewiduje jedynie odpowiedzialność wykroczeniową za naruszenie przepisów o społecznej inspekcji pracy. Zob. art. 22 tej ustawy.

19 Odmienne stanowisko można znaleźć między innymi w wyroku SN z dnia 18 grudnia 2001 r., I PKN 755/00, OSNP 2004, nr 1, poz. 5 oraz w wyroku SN z dnia 3 sierpnia 2006 r., II PK 339/05, OSNP 2007, nr 15-16, poz. 218. Warto zauważyć, że w sprawach, w których wydano te wyroki, społeczni inspektorzy pracy nie zostali wybrani przez uprawnione podmioty. Por. uwagi poczynione niżej.

20 Inaczej przyjął SN w wyrokach przywołanych w przypisie 19.

21 Gdyby nawet dopuścić możliwość zastąpienia wyborów zgodą na rzeczywiste wykonywanie funkcji inspektora przez osoby niewybrane, zgoda powinna być udzielana przez pracowników jako podmiot posiadający czynne prawo wyborcze, a nie przez związki zawodowe. Zob. też w tej kwestii D. Książek, Ustawa..., s. 930-931. 
nie może decydować o nabyciu (lub nienabyciu) przez te osoby statusu inspektora ${ }^{22}$. W przeciwnym razie pracodawca mógłby uznawać za społecznych inspektorów pracy tylko osoby mu sprzyjające, jednocześnie pomijając tych, którzy z różnych względów są dla niego niewygodni. W ten sposób wpływałby on na to, kto reprezentuje wobec niego pracowników.

Statusu społecznego inspektora pracy nie nabywają również osoby wybrane przez nieuprawniony do tego podmiot. Taka sytuacja ma miejsce na przykład wówczas, gdy „inspektorów” wybierają przewodniczący związków zawodowych działających u pracodawcy lub członkowie zarządów tych organizacji ${ }^{23}$. Zdarza się też, że o wyborach jest informowana jedynie część pracowników i tylko ona bierze udział w głosowaniu. Tymczasem aby wybory były ważne, pracownicy muszą mieć możliwość wzięcia w nich udziału. Inna sprawa, czy rzeczywiście z tej możliwości skorzystają. Warto w tym miejscu zauważyć, że ustawa nie wskazuje minimalnego poziomu frekwencji koniecznej do uznania wyborów za ważne.

Jeszcze innym naruszeniem skutkującym nienabyciem statusu inspektora jest brak po stronie wybranych osób legitymacji biernej.

Wskazane byłoby, aby przyjęty wyżej skutek uchybień godzących w istotę zasady reprezentacji znajdował wyraźne odzwierciedlenie w ustawie o społecznej inspekcji pracy. Powinien obowiązywać przepis, z którego wprost wynikałoby, że brak formalnego aktu wyboru oraz naruszenia w zakresie czynnego i biernego prawa wyborczego nie pozwalaja uznać określonych osób za społecznych inspektorów pracy. Z kolei w przypadku pozostałych uchybień można by przyjąć unormowanie odsyłające do przepisów o odwołaniu społecznych inspektorów pracy, nie wykluczając jednak możliwości określenia innych sankcji w regulaminach wyborów.

Uzupełnienie ustawy o społecznej inspekcji pracy o niezbędne unormowania nie powinno ograniczać się jedynie do wprowadzenia regulacji określającej skutki niezgodnego z przepisami wyłonienia inspektorów. Byłoby to niewystarczające. Konieczne wydaje się także wyznaczenie podmiotów, które w razie wątpliwości miałyby kompetencję do ustalania, czy rzeczywiście doszło do naruszeń pociągających za sobą wskazane skutki ${ }^{24}$. De lege lata nie ma bowiem żadnych podmiotów, które mogłyby przeprowadzać w takich

22 Odmienny pogląd zdaje się prezentować B. Cudowski, który analizując wyrok SN z dnia 18 grudnia 2001 r., I PKN 755/00, OSNP 2004, nr 1, poz. 5, stwierdził, że „gdyby pracodawca zakwestionował wcześniej możliwość pełnienia tej funkcji [inspektora - B.R.] ze względu na nieprzeprowadzenie wyborów, to bardzo prawdopodobne byłoby rozstrzygnięcie odmienne", czyli nieuznanie pracownika faktycznie pełniącego funkcję zakładowego społecznego inspektora pracy po upływie wcześniejszej kadencji za podlegającego ochronie na podstawie art. 13 ustawy o społecznej inspekcji pracy. Zob. glosę B. Cudowskiego do wyżej wymienionego wyroku w OSP 2004, nr 11, poz. 147, s. 622.

23 Zob. np. wyrok SN z dnia 18 grudnia 2001 r., I PKN 755/00, OSNP 2004, nr 1, poz. 5; wyrok SN z dnia 3 sierpnia 2006 r., II PK 339/05, OSNP 2007, nr 15-16, poz. 218; wyrok SN z dnia 2 czerwca 2010 r., II PK 371/09, Lex, nr 590317 i postanowienie SN z dnia 7 grudnia 2011 r., II PK 79/11, Lex, nr 1163327.

${ }^{24}$ Wydaje się, że przeprowadzania takiej kontroli nie można by traktować w kategorii udziału w procesie wybierania inspektorów. Odmiennie SN w postanowieniu Kolegium Kompetencyjnego przy Sądzie Najwyższym z dnia 9 listopada 1995 r., III PO 16/95, OSNAPiUS 1996, nr 12, poz. 176. 
przypadkach postępowanie sprawdzające legalność aktu wyłonienia inspektorów. W szczególności takimi podmiotami nie są sądy pracy, co potwierdza orzecznictwo Sądu Najwyższego ${ }^{25}$. Tymczasem istnieje daleko idąca potrzeba kontrolowania prawidłowości wyłaniania społecznych inspektorów pracy, a nawet szerzej - wszystkich przedstawicieli pracowników, ponieważ problem ten nie dotyczy tylko inspektorów. Na potrzebę tę wskazuje praktyka - wydaje się, że wcale nie tak rzadko pracownicy wykonują funkcję społecznych inspektorów pracy, chociaż nie zostali wybrani do jej pełnienia albo ich „wyboru” dokonali przewodniczący lub członkowie zarządów organizacji związkowych. Nieprzyznanie jakimkolwiek podmiotom kompetencji kontrolnych w analizowanym zakresie sprzyja takiej praktyce. Brak możliwości prawnego przeciwdziałania naruszaniu przepisów ustawy regulujących wyłanianie inspektorów pozbawia te przepisy w dużej mierze waloru normatywnego.

Sytuacji nie zmienia fakt, że sądy pracy posiadają kompetencję do oceny zgodności z prawem wyłonienia poszczególnych inspektorów, gdy dokonanie ustaleń w tym zakresie ma istotne znaczenie dla rozstrzygnięcia konkretnych sporów sądowych dotyczących innych spraw. Najczęściej chodzi tutaj o sprawy odnoszące się do szczególnej ochrony inspektorów. Jeżeli nie ma pewności, czy dany pracownik jest rzeczywiście inspektorem, sąd powinien najpierw wyjaśnić istniejące w tym zakresie wątpliwości - posiadanie statusu inspektora warunkuje bowiem korzystanie z ochrony - a dopiero później rozstrzygnąć w przedmiocie sprawy ${ }^{26}$. Wydaje się, że nie stoi temu na przeszkodzie autonomia przedstawicielstw pracowniczych. Nie ma ona bowiem charakteru absolutnego. Przedstawicielstwa pracownicze są zobowiązane do kształtowania swojej działalności $\mathrm{w}$ ramach prawnych wyznaczonych przez ustawodawcę.

\section{Liczba społecznych inspektorów pracy}

Jeszcze innym zagadnieniem, do którego nie odnosi się ustawa o społecznej inspekcji pracy, jest liczba inspektorów, którzy mają działać u pracodawcy na poszczególnych szczeblach. Konkretnych ustaleń w tym przedmiocie nie sposób też dokonać - z powodów określonych wyżej - na podstawie art. 3 ust. 2 ustawy, który jest przywoływany również w kontekście tej kwestii ${ }^{27}$. Brak odniesienia do liczby społecznych inspektorów pracy połączony z odwoływaniem się w tym zakresie do mało precyzyjnego art. 3 ust. 2 ustawy rodzi obawy o wyłanianie zbyt wielu inspektorów. Jak pokazuje praktyka, obawy

${ }_{25}$ Zob. np. postanowienie Kolegium Kompetencyjnego przy Sądzie Najwyższym z dnia 9 listopada 1995 r., III PO 16/95, OSNAPiUS 1996, nr 12, poz. 176; wyrok SN z dnia 3 sierpnia 2006 r., II PK 339/05, OSNP 2007, nr 15-16, poz. 218 i postanowienie SN z dnia 7 grudnia 2011 r., II PK 79/11, Lex, nr 1163327.

26 Zob. np. postanowienie SN z dnia 7 grudnia 2011 r., II PK 79/11, Lex, nr 1163327.

27 P. Pettke, Społeczna inspekcja pracy - instytucja minionego czasu, Praca i Zabezpieczenie Społeczne 2009, 8, s. 11. 
te nie są bezpodstawne ${ }^{28}$. Tymczasem wbrew pozorom większa liczba społecznych inspektorów pracy nie musi przekładać się automatycznie na zapewnienie pracownikom bezpieczniejszych i bardziej higienicznych warunków pracy czy efektywniejszą ochronę ich uprawnień. W przypadku gdy w poszczególnych jednostkach organizacyjnych zakładu pracy działa wielu inspektorów, mogą między nimi powstawać napięcia i konflikty. Trudno przypuszczać, że nie ma to negatywnego wpływu na prowadzoną przez nich działalność - zwłaszcza że brakuje przepisów przewidujących ogólne zasady współpracy między nimi, a także reguły kolizyjne na wypadek sporów kompetencyjnych.

Warto zresztą podkreślić, że wybór znacznej liczby społecznych inspektorów pracy nie jest na ogół dokonywany z myślą o poprawie stanu bezpieczeństwa i higieny pracy czy zwiększeniu skuteczności ochrony uprawnień pracowniczych, lecz w celu objęcia jak największej liczby związkowców szczególną ochroną przed niekorzystną zmianą treści i rozwiązaniem stosunku pracy ${ }^{29}$. Niewykluczone, że stanowi to do pewnego stopnia konsekwencję ograniczenia w 2003 r. zakresu podmiotowego ochrony działaczy związkowych uregulowanej w art. 32 ustawy o związkach zawodowych ${ }^{30}$. Zakładowe i międzyzakładowe organizacje związkowe znalazły alternatywę dla tej ochrony. Alternatywa ta jest bardzo atrakcyjna, jeśli zważyć, że ochrona wypowiedzenia warunków pracy i płacy na ich niekorzyść, a także wypowiedzenia i rozwiązania umowy o pracę, spółdzielczej umowy o pracę oraz stosunku pracy nawiązanego na podstawie mianowania, chyba że zachodzą przyczyny uzasadniające rozwiązanie umowy czy stosunku pracy z mianowania bez wypowiedzenia - wówczas zwolnienie inspektora jest możliwe po uprzednim uzyskaniu zgody statutowo właściwego organu zakładowej (międzyzakładowej) organizacji związkowej ${ }^{31}$.

Istotne jest to, że wybór nadmiernej liczby społecznych inspektorów pracy motywowany dążeniem do zwiększenia grona związkowców szczególnie chronionych powoduje przestawienie znaczenia funkcji pełnionej przez inspektorów i ich ochrony. Sprawowanie przez inspektorów funkcji ukierunkowanej na zapewnienie pracownikom przez pracodawcę bezpiecznych i higienicznych warunków pracy, a także na ochronę uprawnień pracowniczych powinno być najważniejsze. Tymczasem schodzi ono na dalszy plan, a najistotniejsza staje się ochrona inspektorów, która w normalnych okolicznościach odgrywa rolę służebną wobec sprawowanej przez nich funkcji, ma bowiem na celu stworzenie inspektorom właściwych warunków do wykonywania

28 Zob. np. wyrok SN z dnia 30 stycznia 2008 r., I PK 198/07, Lex, nr 394145 oraz K. Rączka, Co dalej ze społeczna inspekcja pracy?, Praca i Zabezpieczenie Społeczne 2008, 9.

29 P. Pettke, Społeczna inspekcja pracy..., s. 8 i n.

30 Ograniczenie to nastąpiło na skutek uchwalenia ustawy z dnia 26 lipca 2002 r. o zmianie ustawy Kodeks pracy oraz o zmianie niektórych innych ustaw (Dz. U., Nr 135, poz. 1146). Zanim ustawa ta weszła w życie, Trybunał Konstytucyjny wydał w kwietniu 2003 r. wyrok, w którym uznał za niekonstytucyjny art. 32 ustawy związkowej w zakresie dotyczącym członków komisji rewizyjnej zakładowej organizacji związkowej (wyrok TK z dnia 7 kwietnia 2003 r., P 7/02, OTK - A 2003, nr 4, poz. 29).

${ }_{31}$ Szerzej na temat ochrony społecznych inspektorów pracy zob. np. W. Sanetra, Ustawa..., jw. oraz D. Książek, Ustawa..., s. 941-945. 
przysługujących im uprawnień. Wydaje się, że w kontekście wskazanego przestawienia znaczenia funkcji i ochrony społecznych inspektorów pracy można uznać, iż wyłanianie zbyt wielu inspektorów stanowi zjawisko z pogranicza patologii.

Zjawisko to może mieć negatywne konsekwencje nie tylko dla jakości pełnienia funkcji przez społecznych inspektorów pracy, lecz także dla działalności prowadzonej przez pracodawcę ${ }^{32}$. Jest oczywiste, że korzystanie przez wielu inspektorów ze szczególnej ochrony treści i trwałości stosunku pracy w znacznym stopniu ogranicza pracodawcę w możliwości swobodnego kształtowania polityki zatrudnienia. Im więcej wyłanianych jest inspektorów, tym większe są też koszty, jakie musi on ponosić z tytułu ich działalności. Nie bez znaczenia jest ponadto fakt, że pełnienie funkcji inspektora przez dużą liczbę pracowników może dezorganizować proces pracy.

Czy de lege lata istnieje wobec tego jakieś rozwiązanie problemu wyłaniania zbyt wielu społecznych inspektorów pracy? Można mieć co do tego wątpliwości, choć reguły wykładni językowo-logicznej i celowościowej przepisów art. 3 ustawy już dzisiaj przemawiają za interpretacją zmierzającą do uznania, iż u danego pracodawcy powinno działać oprócz jednego zakładowego społecznego inspektora pracy tylko tylu oddziałowych (wydziałowych) i grupowych społecznych inspektorów pracy, z ilu oddziałów (wydziałów) i komórek organizacyjnych tych jednostek składa się zakład pracy33.

Interpretacja ta jest na ogół akceptowana w zakresie dotyczącym zakładowego społecznego inspektora pracy. Zgadzając się w pełni z tezą, że u danego pracodawcy może działać wyłącznie jeden inspektor zakładowy, należy jednak zwrócić uwagę na problemy, które to wywołuje w przypadku pracodawcy o bardzo rozbudowanej strukturze organizacyjnej prowadzącego działalność na znacznym obszarze (np. na terenie całego $\mathrm{kraju}^{34}$. U takiego pracodawcy jest z oczywistych względów niezwykle trudno pełnić funkcję zakładowego społecznego inspektora pracy. Co istotne, może to mieć negatywny wpływ na zapewnienie pracownikom bezpiecznych i higienicznych warunków pracy oraz ochronę ich uprawnień. Kluczowy jest tutaj bowiem fakt, że - jak już była o tym mowa wyżej - inspektor zakładowy posiada uprawnienia władcze, których nie mogą wykonywać inni inspektorzy. Warto jednak rozważyć, czy w odniesieniu do wskazanego pracodawcy nie byłoby celowe dopuszczenie w ustawie możliwości wykonywania części uprawnień inspektora zakładowego przez inspektorów oddziałowych (wydziałowych) - czy to w ramach upoważnienia ich do działania w jego imieniu, czy to poprzez przekazanie im jego określonych uprawnień.

Zaprezentowany wyżej kierunek interpretacji nie znajduje natomiast powszechnego poparcia w części odnoszącej się do oddziałowych (wydziałowych) i grupowych społecznych inspektorów pracy. Jest mało prawdopodobne, aby interpretacja ta zyskała

32 Zob. np. K. Rączka, Co dalej ze społeczna inspekcją pracy?, Praca i Zabezpieczenie Społeczne 2008, 9.

33 Por. B. Rutkowska, Szczególna ochrona trwałości stosunku pracy przedstawicieli pracowników - uwagi de lege ferenda, w: Ochrona trwałości stosunku pracy w społecznej gospodarce rynkowej, G. Goździewicz (red.), Warszawa 2010, s. 266.

${ }_{34}$ Por. uwagi na ten temat zawarte w postanowieniu SN z dnia 7 grudnia 2011 r., II PK 79/11, Lex, nr 1163327. 
ogólną akceptację w najbliższej przyszłości. Trudno też oczekiwać, że nagle zostanie zaprzestana praktyka wybierania nadmiernej liczby inspektorów. Jak się wydaje, do kontynuowania tej praktyki przyczynia się dodatkowo świadomość, że skoro nie ma przepisów odnoszących się do liczby społecznych inspektorów pracy, nie ma też unormowań przewidujących skutki wyłonienia zbyt wielu inspektorów ani regulacji przyznającej określonym podmiotom - np. sądom pracy - kompetencji do decydowania o tych skutkach w konkretnych stanach faktycznych.

W świetle poczynionych uwag wydaje się, że nie pozostaje nic innego, jak znowelizowanie ustawy o społecznej inspekcji pracy poprzez uregulowanie liczby inspektorów uprawnionych do działania u pracodawcy. Nie chodzi oczywiście o wskazanie konkretnej liczby inspektorów, ale o wyraźne zaznaczenie, że w ramach danego oddziału (wydziału) czy komórki organizacyjnej oddziału (wydziału) ujętej w strukturze organizacyjnej pracodawcy może pełnić funkcję tylko jeden inspektor. Aby zagwarantować przestrzeganie tej regulacji, należałoby ją połączyć z wyraźnym określeniem skutków jej naruszenia. $\mathrm{W}$ razie gdyby skutki te nie miały następować $\mathrm{z}$ mocy prawa, trzeba by także wprost wskazać podmioty kompetentne do decydowania o ich zastosowaniu.

Jeszcze innym rozwiązaniem, które zapewne ukróciłoby praktykę wybierania nadmiernej liczby społecznych inspektorów pracy, mogłoby być ograniczenie zakresu podmiotowego szczególnej ochrony inspektorów. Czy rozwiązanie to jest jednak uzasadnione? Rozważając tę kwestię, trzeba na wstępie zauważyć, że - tak jak w odniesieniu do pozostałych przedstawicieli pracowników - zakres podmiotowy ochrony inspektorów powinien być ukształtowany na podstawie kryterium stopnia konfliktogenności pełnionej przez nich funkcji. Jest on determinowany w szczególności charakterem przysługujących inspektorom uprawnien ${ }^{35}$. Nie bez znaczenia jest zatem w tym kontekście fakt, że tylko zakładowy społeczny inspektor pracy posiada uprawnienia władcze - prawo do składania pisemnych zaleceń usunięcia uchybień w zakresie bezpieczeństwa i higieny pracy oraz wstrzymania w określonych okolicznościach pracy danego urządzenia technicznego lub określonych robót, a także prawo występowania $\mathrm{z}$ wnioskiem do Państwowej Inspekcji Pracy o przeprowadzenie kontroli ${ }^{36}$. Pozostałym społecznym inspektorom pracy przysługują uprawnienia o charakterze niestanowczym. O ile więc nie ulega wątpliwości, że inspektor zakładowy naraża się na represje i szykany ze strony pracodawcy w stopniu uzasadniającym jego szczególną ochronę, o tyle nie jest to już tak oczywiste w przypadku inspektorów oddziałowych (wydziałowych) i grupowych. Sprawowana przez nich funkcja jest mniej konfliktogenna. Wydaje się, że w odniesieniu do tych inspektorów można by rozważyć zastąpienie dotychczasowej ochrony ochroną analogiczną do tej, z której korzystają przedstawiciele uczestniczący w konsultacjach $\mathrm{z}$ zakresu bezpieczeństwa i higieny pracy ${ }^{37}$. Zgodnie $\mathrm{z}$ art. $237^{11 \mathrm{a}} \S 6 \mathrm{kp}$ przedstawiciele

${ }_{35}$ O czynnikach determinujących konfliktogenny charakter funkcji społecznego inspektora pracy pisze W. Szubert, Ochrona..., s. 135 i n.

36 Zob. art. 11 i 19 ustawy o społecznej inspekcji pracy.

37 B. Rutkowska, Szczególna ochrona..., s. 266. 
ci nie mogą ponosić jakichkolwiek niekorzystnych dla nich konsekwencji z tytułu prowadzonej działalności. Takie wyraźne wykluczenie możliwości ponoszenia przez inspektorów oddziałowych (wydziałowych) i grupowych negatywnych konsekwencji z tytułu prowadzonej działalności byłoby natomiast niewystarczające, gdyby mieli oni wykonywać uprawnienia stanowcze. Wówczas powinni być chronieni podobnie jak inspektor zakładowy.

\section{Uwagi końcowe}

W świetle przeprowadzonych wyżej rozważań widać, że z liczby nowelizacji ustawy o społecznej inspekcji pracy nie należy w żadnym razie wyprowadzać wniosku o jej wysokim poziomie legislacyjnym. Przeciwnie - ustawa ta ma wiele mankamentów, które świadczą o tym, że część jej przepisów nie w pełni odpowiada zasadom techniki prawodawczej przewidzianym w rozporządzeniu w sprawie „Zasad techniki prawodawczej”. Niektóre regulacje ustawy o społecznej inspekcji pracy są na przykład na tyle ogólne, że wywołują poważne wątpliwości interpretacyjne. Jedna z zasad techniki prawodawczej przewiduje co prawda, że jeżeli zachodzi potrzeba zapewnienia elastyczności tekstu aktu normatywnego, można posłużyć się określeniami nieostrymi, klauzulami generalnymi albo wyznaczyć nieprzekraczalne dolne lub górne granice swobody rozstrzygnięcia ( $\$ 155$ „Zasad techniki prawodawczej”), niemniej nie oznacza to - jak się wydaje dopuszczalności przyznania adresatom normy pełnej dowolności działania, a taki kierunek interpretacji zdaje się obecnie przeważać na przykład na gruncie przepisu stanowiącego o dostosowywaniu przez związki zawodowe organizacji inspekcji do potrzeb wynikających ze struktury pracodawcy. Przyjmowana interpretacja powyżzzego przepisu wpływa niestety negatywnie na praktykę jego stosowania.

Niektóre przepisy zdają się z kolei nie do końca wyczerpująco regulować określone aspekty działania inspekcji i inspektorów. Nie oznacza to oczywiście, że ustawa powinna drobiazgowo regulować wszystkie związane z tym kwestie. Jest to nawet niewskazane. W myśl jednak $\$ 2$ „Zasad techniki prawodawczej” ustawa powinna wyczerpująco regulować daną dziedzinę spraw, nie pozostawiając poza zakresem swego unormowania istotnych fragmentów tej dziedziny. Odniesienie tego wymogu do ustawy o społecznej inspekcji pracy jest równoznaczne z powinnością uregulowania w tej ustawie wszelkich kwestii, które w istotny sposób wpływają na działalność inspekcji i inspektorów w praktyce. Dotyczy to na przykład określenia konsekwencji braku formalnego aktu wyboru inspektorów czy wadliwości tego aktu polegającej na naruszeniu czynnego lub biernego prawa wyborczego, wyznaczenia podmiotów, które byłyby kompetentne do dokonywania ustaleń w tym przedmiocie, czy wskazania liczby inspektorów mogących działać u pracodawcy (w połączeniu z przyjęciem konkretnych skutków przekroczenia tej liczby i uprawnieniem określonych podmiotów do decydowania o ich zastosowaniu). Brak uregulowania tych kwestii prowadzi do powstawania w praktyce zjawisk z pogranicza patologii. Najlepszym tego przykładem jest dokonywanie wyboru 
bardzo wielu społecznych inspektorów pracy w celu poszerzenia grona związkowców objętych szczególną ochroną.

Mając powyższe na względzie, konieczne wydaje się przeprowadzenie daleko idącej nowelizacji ustawy o społecznej inspekcji pracy. Jak wynika z rozważań przeprowadzonych w niniejszym opracowaniu, nowelizacja ta powinna polegać na doprecyzowaniu i uzupełnieniu szeregu przepisów.

Wskazana byłaby także zmiana niektórych z przyjętych w ustawie rozwiązań. Biorąc pod uwagę fakt, że u podstaw potrzeby modyfikacji tych rozwiązań leżą przemiany społeczno-gospodarcze i przekształcenia ustrojowe, jakie nastąpiły w Polsce po 1989 r., podkreślone uchwaleniem nowej Konstytucji RP, która wyznacza ramy dla ustawodawstwa zwykłego, warto zastanowić się, czy zamiast znowelizowania obowiązującej ustawy nie lepsze byłoby jednak uchwalenie zupełnie nowej ustawy o społecznej inspekcji pracy. Przemawia za tym również $\$ 84$ „Zasad techniki prawodawczej”, zgodnie z którym jeżeli zmiany wprowadzane w ustawie miałyby być liczne albo miałyby naruszać konstrukcję lub spójność ustawy, albo gdy ustawa była już poprzednio wielokrotnie nowelizowana, opracowuje się projekt nowej ustawy.

Przygotowując nową ustawę, można by nie tylko zapewnić pełną zgodność jej przepisów z zasadami techniki prawodawczej, ale także kompleksowo dostosować społeczną inspekcję pracy do dzisiejszych uwarunkowań. W tym celu należałoby między innymi zrealizować zgłoszone w niniejszym opracowaniu postulaty przyznania również niepracownikom prawa wyboru społecznych inspektorów pracy, a także uniezależnienia inspekcji i inspektorów od organizacji związkowych. Wobec znaczącej zmiany struktury zatrudnienia, do jakiej doszło w ciągu ostatnich 30 lat, trzeba by też na nowo ustalić, u jakich pracodawców powinna działać inspekcja, a w szczególności czy zakresem jej odniesienia mogą być objęci mikro-, mali i średni przedsiębiorcy, zważywszy z jednej strony na cel realizowany przez inspekcję, z drugiej strony - wpływ obecności inspekcji na działalność prowadzoną przez tych przedsiębiorców. Dokonania takiej oceny wymaga od niedawna ustawa o swobodzie działalności gospodarczej ${ }^{38}$. Wydaje się, że należałoby też przeanalizować coraz częściej zgłaszaną w nauce prawa pracy propozycję zmiany formuły działania inspekcji ${ }^{39}$.

38 Wymóg ten przewiduje art. 103 pkt la ustawy z dnia 2 lipca 2004 r. o swobodzie działalności gospodarczej (Dz. U. z 2016 r., poz. 1829 ze zm.). Przepis ten został dodany przez art. 1 ustawy z dnia 26 stycznia 2017 r. o zmianie ustawy o swobodzie działalności gospodarczej (Dz. U., poz. 460).

39 Warto w tym kontekście podkreślić, że już na gruncie ustawy o społecznej inspekcji pracy z $1950 \mathrm{r}$. W. Szubert uważał, iż „[r] ealne osiągnięcia [w dziedzinie bezpieczeństwa i higieny pracy - B.R.] zależą (...) przede wszystkim od konstruktywnej współpracy załóg z kierownictwem zakładów opartej na zrozumieniu wspólnych celów i zaufaniu. Współpraca taka (...) wymaga zastosowania form organizacyjnych, które by nie przeciwstawiały pracowników kierownictwu, lecz stwarzały wspólną platformę działania” (W. Szubert, Ochrona..., s. 138-139). Por. M. Seweryński, Załoga zakładu pracy..., s. 54-55. Zob. też B. Krzyśków, Dyrektywa Rady 89/391/EWG w sprawie wprowadzenia środków sprzyjających poprawie bezpieczeństwa i higieny pracy a prawo polskie, PiPGUE 1999, nr 4. 
Czas pokaże, czy obecnie obowiązująca ustawa o społecznej inspekcji pracy zostanie znowelizowana lub zastąpiona nową ustawą. Najgorszym z możliwych scenariuszy byłoby natomiast pozostawienie jej bez jakichkolwiek zmian.

\section{Bibliografia}

Florek L., Europejskie prawo pracy, Warszawa 2010.

Kozieł W., Ustawa o społecznej inspekcji pracy. Komentarz, Warszawa 1988.

Książek D., Ustawa o społecznej inspekcji pracy, w: Zbiorowe prawo pracy, K. Baran (red.), Warszawa 2014.

Pettke P., Społeczna inspekcja pracy - instytucja minionego czasu, Praca i Zabezpieczenie Społeczne 2009, 8.

Piątkowski J., Uprawnienia zakładowej organizacji związkowej, Torun 2008.

Rączka K., Co dalej ze społeczna inspekcja pracy?, Praca i Zabezpieczenie Społeczne 2008, 9.

Rutkowska B., Szczególna ochrona trwałości stosunku pracy przedstawicieli pracowników - uwagi de lege ferenda, w: Ochrona trwałości stosunku pracy w społecznej gospodarce rynkowej, G. Goździewicz (red.), Warszawa 2010.

Salwa Z., Uprawnienia związków zawodowych, Bydgoszcz 1998.

Sanetra W., Ochrona praw pracowniczych, w: Polskie prawo pracy w okresie transformacji w oświetleniu prawa wspólnotowego, H. Lewandowski (red.), Warszawa 1997.

Sanetra W., Ustawa o społecznej inspekcji pracy. Komentarz, w: Prawo socjalne, W. Sanetra (red.), Warszawa 2001.

Seweryński M., Załoga zakładu pracy - uwagi de lege ferenda, w: Reprezentacja praw i interesów pracowniczych, G. Goździewicz (red.), Toruń 2001.

Sobczyk A., Prawo pracy w świetle Konstytucji RP, t. I, Teoria publicznego i prywatnego indywidualnego prawa pracy, Warszawa 2013.

Szubert W., Ochrona pracy. Studium społeczno-prawne, Warszawa 1966.

Świątkowski A., Międzynarodowe prawo pracy, t. I, Międzynarodowe publiczne prawo pracy standardy międzynarodowe, vol. 3, Warszawa 2008.

Wyka T., Ochrona zdrowia i życia pracownika jako element treści stosunku pracy, Warszawa 2003.

Wyka T., Ochrona zdrowia i życia pracowników jako zadanie związku zawodowego, w: Związkowe przedstawicielstwo pracowników zakładu pracy, Z. Hajn (red.), Warszawa 2012. 